DOI: $10.1515 / \mathrm{sjdv}-2015-0002$

\title{
Treatment of Verrucous Epidermal Nevus by Radiofrequency Ablation: a Case Report
}

\author{
Dragana LJUBISAVLJEVIĆ ${ }^{*}$, Zorana ZLATANOVIĆ ${ }^{1}$, Radmila MILENKOVIĆ ${ }^{1}$, \\ Danijela POPOVIĆ ${ }^{1}$, Mirjana PARAVINA² \\ ${ }^{1 *}$ Clinic of Skin and Venereal Diseases, Clinical Center of Nišs, Serbia \\ ${ }^{2}$ Medical Faculty, University of Nišs, Serbia
}

*Correspondence: Dragana Ljubisavljević, E-mail: nebodra@yahoo.com

DE GRUYTER OPEN

UDC 616.591-006.8-056.7-08

\begin{abstract}
Verrucous epidermal nevi are noninflammatory, congenital, cutaneous hamartomas composed of keratinocytes, abnormal clone(s) of cells that reflect genetic mosaicism arising from different somatic mutations. Some of these mutations are well recognized, but some are still unidentified. Molecular techniques are used for identification and classification of molecular causes of certain epidermal nevi, whereas all verrucous epidermal nevi are divided into epidermolytic and non-epidermolytic types. They are typically present at birth, but may appear during childhood, even later. Their prevalence in adults ranges from 0.1 to $0.5 \%$, equally affecting both sexes, and about 1 in 1000 newborns.

Warty, brown papules without inflammation distinguish verrucous nevi from other epidermal nevi, while presence at birth and persistance distinguish verrucous epidermal nevi from linear viral warts. Epidermolytic and non-epidermolytic verrucous epidermal nevi are almost always hard to distinguish, except by histology. As a rule, verrucous epidermal nevi are asymptomatic, they have a benign course, except occasionally, and therapy is mostly used for cosmetic reasons. Simple excision is usually the treatment of choice. Topical agents are rarely curative, as well as surgery which is associated with relapses, unless both epidermis and the underlying dermis are removed or destroyed at the same time.

We present a case of an otherwise healthy 21 -year-old female patient, who presented with a solitary congenital verrucous cauliflower-like lesion in the right zygomatic region of the face. The lesion was present from birth. Due to its gradual growth during years, the lesion became a great esthetic and functional problem for this young patient. There was no family history of similar or any other tumorous skin lesions in the family. On examination, the patient had a solitar unilateral, well defined yellowish cauliflower-like verrucous lesion confined to the right malar side of the face. The lesion was distributed along the lines of Blaschko extending horizontally, from its wider $1.5 \mathrm{~cm}$ cauliflower-like part on the right zygomatic region, towards its tail-like $0.5 \mathrm{~cm}$ thick end on the preauricular region, in approximately $3 \mathrm{~cm}$ long tail-like manner without crossing the midline. Since the patient refused biopsy, no exact differentiation between epidermolytic and non-epidermolytic nevi was possible. The diagnosis of verrucous epidermal nevus was based on history and clinical presentation, as a diagnosis of exclusion. Due to the fact that patients with epidermolytic verrucous epidermal nevi are at risk of parenting a child with bullous ichthyosiform erythroderma, the patient was counseled on this risk, and on the possibility of first-trimester antenatal diagnosis. The lesion was successfully treated by radio-wave surgery.
\end{abstract}

\section{Key words}

Nevus, Sebaceous of Jadassohn; Prevalence; Diagnosis; Ablation Techniques; Case Reports; Catheter Ablation

ccording to a rather historical, but still existing
fursification, all nevi are generally classified and
further subdivided based upon the origin of their
component cells, tissues or organs and according to
the macroscopic or histological features, respectively.
Thus, epidermal nevi are composed of keratinocytes

(C) 2015 The Serbian Association of Dermatovenereologists
$(1,2,3)$ and categorized as follows: keratinocyte nevi, sebaceous nevi, follicular nevi, apocrine nevi, eccrine nevi, inflammatory epidermal nevi, other nevoid epidermal disorders (linear lichen planus, nevoid psoriasis, linear porokeratosis, HaileyHailey-like epidermal nevus, Darier-like epidermal 
nevus, atrophoderma of Moulin, 'blaschkitis'), and epidermal nevus syndrome (3). Since more research has been recently conducted in order to clarify the molecular basis of certain epidermal nevi, it has been suggested that probably all epidermal nevi comprise an abnormal clone of cells, as a consequence of genetic mosaicism arising from a somatic mutation $(3,4)$. By using molecular techniques for the identification and classification of molecular causes of certain epidermal nevi, all verrucous epidermal nevi are divided into epidermolytic and non-epidermolytic types. Epidermolytic and non-epidermolytic verrucous epidermal nevi are almost always hard to distinguish except by histology (due to presence/absence of epidermolytic hyperkeratosis), which is important because contrary to non-epidermolytic nevi, a parent with an epidermolytic verrucous epidermal nevus is at risk to have gonadal mosaicism as well as cutaneous mosaicism and to produce offspring with generalized autosomal dominant bullous ichthyosiform erythroderma (BIE). Though the risk has not been exactly quantified, counseling may be of benefit for affected individuals and their families (3).

Warty, brown papules without inflammation distinguish verrucous nevi from other epidermal nevi, while presence at birth and persistence distinguish verrucous epidermal nevi (VEN) from linear viral warts $(3,5)$.

VEN are the most common type among all other epidermal nevi. They are usually present at birth, but may appear during childhood, even later. Thus, their prevalence in adults ranges from 0.1 to $0.5 \%$, equally affecting both sexes, and about 1 in 1000 newborns $(3,6,7,8)$.

They are expected to be blistered at birth, and only later to become verrucous. At birth, in the majority of cases, VEN have a macerated, whitish appearance, but within a few days they become pink or slightly pigmented velvety streaks or plaques. In young children they appear as slightly pigmented velvety or warty streaks or plaques. Their extent and distribution may considerably vary $(3,5)$.

As a rule, verrucous epidermal nevi are asymptomatic, they generally have a benign course, except on rare occasions, thus, the therapy is mostly used for cosmetic reasons (9).

Various therapeutic modalities have been attempted (10 - 13). Topical agents are rarely curative, as well as surgery. Simple excision is usually the treatment of choice, but relapses may occur (3). World literature reports show that a great majority of treatment outcomes of verrucous epidermal nevi using various therapeutic modalitites, do not differentiate epidermolytic and non-epidermolytic nevi (3).

\section{Case Report}

We present a case of an otherwise healthy 21-year-old female patient with a solitary congenital verrucous cauliflower-like lesion in the right zygomatic region of the face. The lesion was present from birth in a form of a small, verrrucous papule which gradually became more verrucous.

Due to its gradual growth during years, the lesion became a great esthetic and functional problem for this young patient. There was no family history of similar or any other tumorous skin lesion in the family.

On examination, the patient had a solitary unilateral, well defined yellowish cauliflower-like verrucous lesion confined to the right malar side of the face. The lesion was distributed along the lines of Blanschko, extending horizontally, from its wider $1.5 \mathrm{~cm}$ cauliflower-like part on the right zygomatic region, towards its tail-like $0.5 \mathrm{~cm}$ thick end on the preauricular region, in approximately $3 \mathrm{~cm}$ long taillike manner without crossing the midline (Figure 1).

Since the patient refused biopsy, no exact differentiation between epidermolytic and nonepidermolytic nevi was possible. The diagnosis of verrucous epidermal nevus was based on history and clinical presentation, as a diagnosis of exclusion. Due to the fact that patients with epidermolytic verrucous epidermal nevi are at risk of parenting a child with bullous ichthyosiform erythroderma (BIE), the patient was counseled on this risk and on the possibility of first-trimester antenatal diagnosis.

The lesion was successfully treated by radiowave radiosurgery (radiofrequentcy knife: Proxima VF, Proxima D.O.O, 18250 Niš, Srbija) under local anesthetic cream (EMLA). An electrode tip in the shape of a fine needle cutting with coagulation selected position of waveform output power of $6 / 7$ was used in the first session (range between 0 and 9). A second session was performed 7 days later, the edges were melted by spherical electrode tip, using the same position and intensity (Figure 2). 


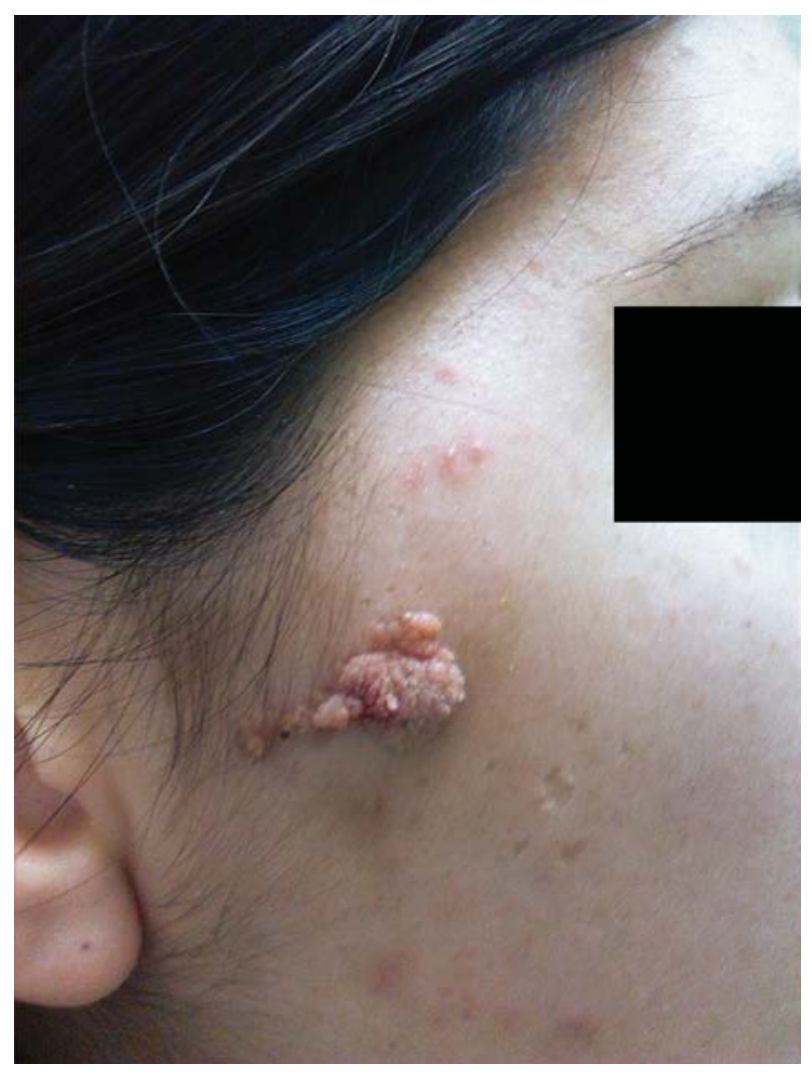

Figure 1. Facial lesion before treatment

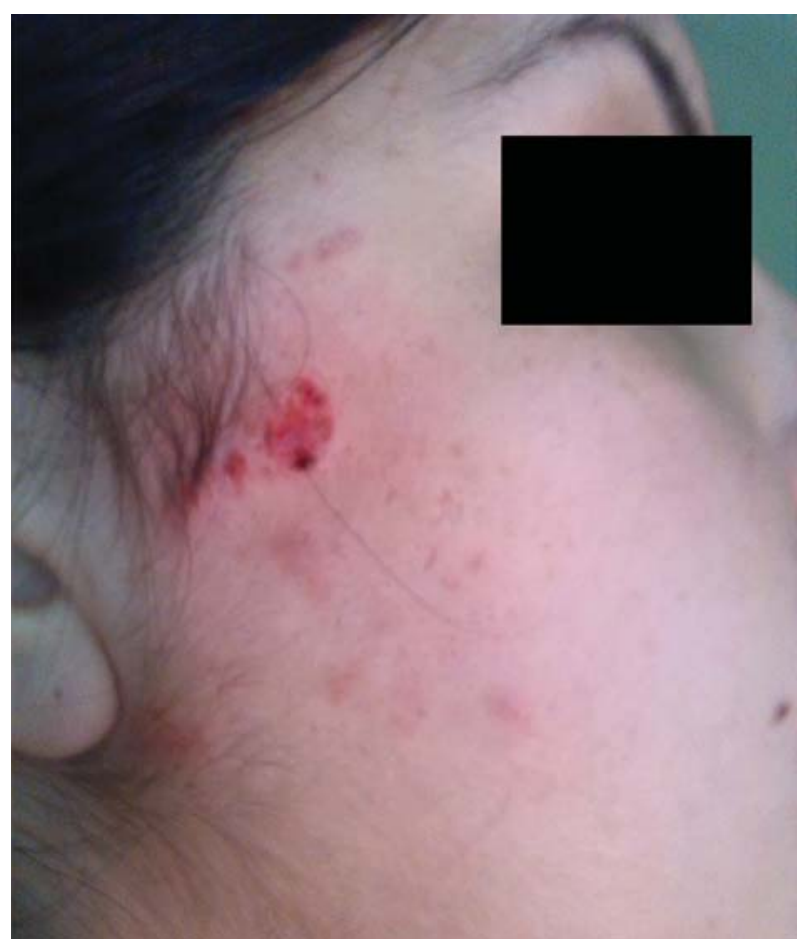

Figure 2. Affected area immediately after the treatment
Further therapy included local use of antibiotic ointments and anti-scar gel (Figure 3). On 4 week follow-up, VEN was totally removed, with no scars, with only mild erythema on previously affected skin (Figure 4). Due to the fact that VEN can recur, partially or completely, the patient was advised to do regular follow-ups, as well as maximum sun protection during summer months.

\section{Discussion}

Verrucosus epidermal nevi (VEN) account for more than $60 \%$ of all epidermal nevi (14). They can occur at birth, early childhood, or at later age $(7,8)$. The size and number of nevi varies. Most frequently they are localized on the limbs or trunk, and less commonly on the face or neck $(15,16)$. Oral mucosal has rarely been reported due to extension of nevi on the adjacent mucosal surface (17). These lesions virtually never cross the midline. Both, the shape and distribution of almost all epidermal nevi including verrucous, follow the pattern of Blaschko's lines that are features of mosaic conditions of the epidermis and probably the paths of ectodermal cell migration from the neural crest (3). Rarely, lesions may occur on both sides (18). As a rule, VEN are asymptomatic. The lack of inflammation, presence at birth, warty, brown appearance and persistence distinguish them from most other types of epidermal nevi (19). In the past, verrucous epidermal nevi have been confused with a certain number of other epidermal nevi distinct from VEN, that have been recognized more recently $(3,20)$.

As it has been previously mentioned, after identifying the molecular causes of certain epidermal nevi, all VEN are divided into epidermolytic and non-epidermolytic types that are almost always hard to distinguish except by histology. In our patient, who refused biopsy, the diagnosis of verrucous epidermal nevus was made based on history and clinical presentation, as a diagnosis of exclusion. Due to mosaicism, both epidermolytic and non-epidermolytic VEN are sporadic and cannot be passed on from parent to child and recur in the same family. However, in light of the new molecular data, epidermolytic and non-epidermolytic verrucous epidermal nevi should be distinguished histologically. VEN represent a noninflammatory congenital cutaneous hamartomas composed of keratinocytes that are abnormal clone/ 


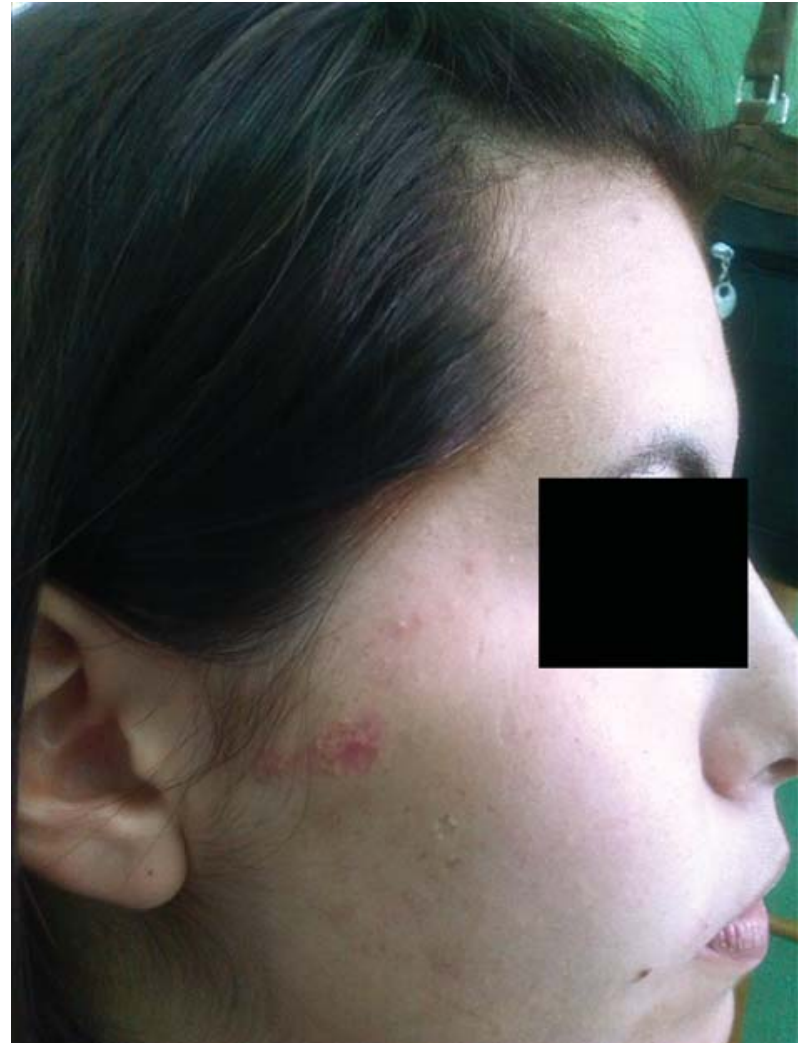

Figure 3. Treated area 7 days after the therapy

clones of cells that reflect genetic mosaicism which arises from different somatic mutations $(3,21,22)$. Some of these mutations are well recognized, but some are still unidentified (3). It has been confirmed that epidermolytic VEN represent clones of cells expressing a mutation in one of the bullous ichthyosiform erythroderma (BIE) gene: $K R T 10(21,23)$ or $K R T 1$ (24). Such VEN cannot be passed on from parent to child, but contrary to nonepidermolytic VEN, that present mosaicism for different, and as yet unidentified, mutations, a parent with an epidermolytic VEN may have gonadal mosaicism as well as skin mosaicism, and can therefore produce offspring with generalized BIE $(21,24$ - 27). Though the risk has not been exactly calculated yet, efforts should be made to counsel affected individuals (3).

In contrast to epidermolytic VEN, where mutations affect keratin genes that are expressed only in epithelia, non-epidermolytic VEN, which represent mosaic expression of still unidentified mutations, may (in approximatelly 10\%) be associated with extracutaneous abnormalities particularly of the central nervous system, eye and skeleton (e.g. epidermal nevus syndrome) $(3,28)$. Several other changes have been reported in verrucous epidermal nevi, such as Bowen's disease, verrucous and adnexal carcinomas $(3,29)$, basal cell $(30)$ and squamous cell carcinomas $(31,32)$ within epidermal nevi. However, it has not yet been claryfied whether these represent age and/ or site-dependent differences in the same condition or different nevi (3). In our patient there were no such associations. The management of the associated anomalies requires careful clinical and noninvasive relevant investigations, including ophthalmological examination and cranial ultrasound (3).

Therapeutic modalities are numerous and they are used depending on the localization and size of the lesion with different level of success (9). Topical or intralesional corticosteroids were used, as well as calcipotriol, 5-fluorouracil, podophyllin, retinoid, chemical peeling $(33,34)$, cryotherapy, dermabrasion, electrosurgery $(1,2)$, photodynamic therapy $(11)$, different types of lasers, such as argon (35) ruby (36), erbium: yttrium aluminium garnet (Er : YAG) (37), carbon dioxide laser $(2,9,10,35,38$ - 40).

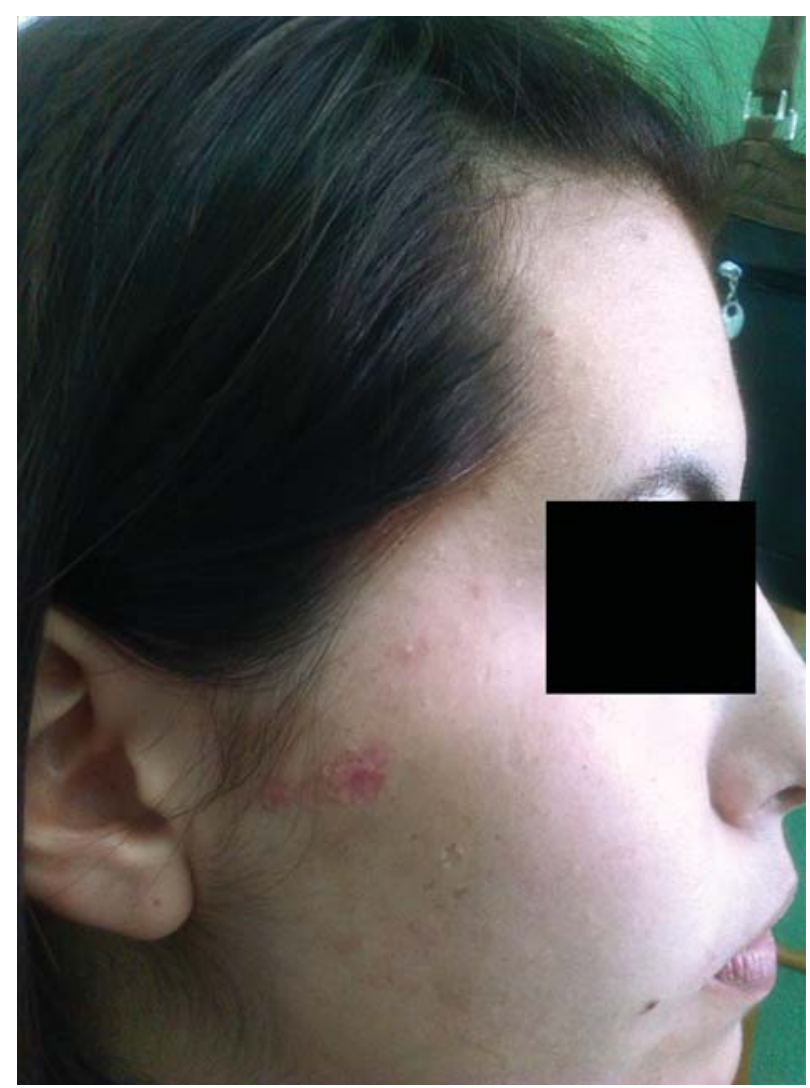

Figure 4 Treated area 4 weeks after the therapy 
In the recent years, radiofrequency ablation (radiosurgery, high frequency electrosurgery) has become a very important and effective tool in dermatosurgical everyday practice $(41,42)$. Therefore, we conducted a radio wave technique for surgical management of VEN in our patient. The radio wave probe Proxima VF is a modern highfrequency radio surgical instrument which converts electrical current into radio wave frequency on the principle of increasing the frequency and voltage and simultaneously decreasing the amperage of alternating current. By further modification, different wave forms are produced, with three main tissue effects: electrosection (cutting), electrocoagulation (deep tissue destruction) and electrodessication/ electrofulguration (superficial tissue destruction). The selection of wave form as well as the shape of probes (fine needle, wire loop, ellipse or triangle, diamond), depend on the primary aim, e.g. cutting or coagulation $(41,42)$. Radiofrequency ablation has become popular because of several advantages in comparison to other surgical procedures, particularly electric cautery, surgical excision and laser treatment. It is a simple, time-consuming, less painful, rather safe technique, causing less lateral heat spread and tissue damage, with fewer side effects and complications (41 - 45). Nevertheless, regardless of the therapy used, a high relapse rate has been reported, thus follow up is therefore advised (3)

\section{Conclusion}

This is a report of a localized congenital verrucous epidermal nevus in an otherwise healthy young woman, who was successfully treated by radiofrequency ablation.

\section{References}

1. Panagiotopoulos A, Chasapi V, Nikolaou V, Stavropoulos PG, Kafouros K, Petridis A, et al. Assessment of cryotherapy for the treatment of verrucous epidermal naevi. Acta Derm Venereol 2009;89:292-4.

2. Lapidoth M, Israeli H, Ben Amitai D, Halachmi S. Treatment of verrucous epidermal nevus: experience with 71 cases. Dermatology 2013;226:342-6.

3. Moss C, Shahidullah H. Naevi and other developmental defects. In: Burns DA, Breathnach SM, Cox NH, Griffiths SEM, editors. Rook's texbook of dermatology. 8th edition. Oxford: Blackwel Publishing Ltd; 2010. p. 18.4.

4. Rogers M, McCrossin I, Commens C. Epidermal nevi and the epidermal nevus syndrome: a review of 131 cases. J Am Acad Dermatol 1989;20:476-88.

5. Shafi M, Khatri ML, Sen NK. Extensive verrucous epidermal naevus. J Eur Acad Dermatol Venereol 2001;15:269-70.

6. Vujevich JJ, Mancini AJ. The epidermal nevus syndromes: multisystem disorders. J Am Acad Dermatol 2004;50:957-61.

7. Adams BB, Mutasim DF. Adult onset verrucous epidermal nevus. J Am Acad Dermatol 1999;41(5 Pt 2):824-6.

8. Kim R, Marmon S, Kaplan J, Kamino H, Pomeranz MK. Verrucous epidermal nevus. Dermatol Online J 2013;19(12):20707.

9. Alonso-Castro L, Boixeda P, Reig I, de Daniel-Rodriguez C, Fleta-Asin B, Jaen-Olasolo P. Carbon dioxide laser treatment of epidermal nevi: response and long-term follow-up. Actas Dermosifiliogr 2012;103:910-8.

10.Paradela S, Del Pozo J, Fernandez-Jorge B, Lozano J, Martinez-Gonzales C, Fonzeca E. Epidermal nevi treated by carbon dioxide laser vaporization: a series of 25 patients. J Dermatolog Treat 2007;18:169-74.

11.Sim JH, Kang Y, Kim YC. Verrucous epidermal nevus successfully treated with photodynamic therapy. Eur J Dermatol 2010;20:814-5.

12.Parera E, Gallardo F, Toll A, Gil I, Sanchez-Schmidt J, Pujol R. Inflammatory linear verrucous epidermal nevus successfully treated with methyl-aminolevulinate photodynamic therapy. Dermatol Surg 2010;36:253-6.

13.Pearson JC, Harland CC. Epidermal naevi treated with pulsed erbium: YAG laser. Clin Exp Dermatol 2004;29:494-6.

14.Lambert D. Naevus epidermiques. In: Saurat JH, Grosshans E, Laugier P, Lachapelle JM, editors. Dermatologie et venereologie. 2ieme edition. Paris: Masson; 1990. p. 224-6.

15.Toussaint S, Salcedo E, Kamino H. Benign epidermal proliferations. Adv Dermatol 1999;14:307-57.

16. Rogers M. Epidermal nevi and the epidermal nevus syndromes: a review of 233 cases. Pediatr Dermatol 1992;9:342-4.

17.Colleti G, Allevi F, Moneghini L, Rabbiosi D, Bertossi D, Frau I, et al. Epidermal nevus and ameloblastoma: a rare association. Oral Surg Oral Med Oral Pathol Oral Radiol 2014;117(3):e275-9.

18. Elewski BE, Hughey LC, Parsons ME. Differential diagnosis in dermatology. Philadelphia: Elsevier Mosby; 2005. p. 263.

19. Thomas D, Swanson NA, Lee KK. Benign epithelial tumors, hamartomas and hyperplasias. In: Wolff K, Goldsmith LA, Katz SI, Gilchrest BA, Paller AS, Leffell DJ, editors. Fitzpatrick dermatology in general medicine. 7th edition. New York: McGraw Hill Med; 2008. p. 1056-94.

20. Wolf K, Johnson RA, Suurmond D. Color atlas and synopsis of clinical dermatology. New York: McGraws-Hill; 2005. p. 214-5.

21. Paller AS, Syder AJ, Chan YM, Yu QC, Hutton E, Tadini G, et al. Genetic and clinical mosaicism in a type of epidermal nevus. N Engl J Med 1994;331:1408-15.

22. Moss C. Cytogenetic and molecular evidence for cutaneous mosaicism: the ectodermal origin of Blaschko lines. Am J Med Genet 1999;85:330-3.

23. Moss C, Jones DO, Blight A, Bowden PE. Birthmark due to cutaneous mosaicism for keratin 10 mutation. Lancet 1995;345(8949):596.

24.Tsubota A, Akiyama M, Sakai K, Goto M, Nomura Y, Ando 
$S$, et al. Keratin 1 gene mutation detected in epidermal nevus with epidermolytic hyperkeratosis. J Invest Dermatol 2007;127:1371-4.

25. Atherton DJ. Naevi and other developmental defects. In: Champion RH, Burton JL, Burns DA, Breathnach SM, editors. Rook's textbook of dermatology. Oxford: Blackwell Sci; 1998. p. 519-616.

26. Ančevski A, Pavlović MD, Karadaglić Đ. Benigne proliferacije epiderma. In: Karadaglić Đ, editor. Dermatologija. Beograd: Vojnoizdavački zavod; 2000. p. 842-57.

27. Albers KM. Keratin biochemistry. Clin Dermatol 1996;14:309-20.

28. Das A, Sen A, Mishra V. Linear non-epidermolytic verrucous epidermal nevus. Indian Pediatr 2014;51:591.

29. Vidaurri-de la Cruz H, Tamayo-Sanchez L, Duran-McKinster C, de la Luz Orozco-Covarrubias M, Ruiz-Maldonado R. Epidermal nevus syndromes: clinical findings in 35 patients. Pediatr Dermatol 2004;21(4):432-9.

30.Zheng LQ, Hunang Y, Qu YJ, Zhang YH, Han XC. Multiple basal cell carcinomas arising in a epidermal nevus. J Dermatol 2013;40:482-3.

31. Toya M, Endo Y, Fujisawa A, Tanioka M, Yoshikawa Y, Tachibana $T$, et al. A metastasizing squamous cell carcinoma arising in a solitary epidermal nevus. Case Rep Dermatol Med 2012;109:109632.

32. Riad H, Mansour K, Sada HA, Naama KA, Shaigy AA, Hussain K. Fatal metastatic cutaneous squamous cell carcinoma evolving from a localized verrucous nevus. Case Rep Dermatol 2013;5:272-82.

33. Fox BJ, Lapins NA. Comparison of treatment modalities for epidermal nevus: a case report and review. J Dermatol Surg Oncol 1983;9:879-85.

34. Toyozawa S, Yamamoto Y, Kaminaka C, Kishioka A, Yonei
N, Furukawa F. Successful treatment with trichloroacetic acid peeling for inflammatory linear verrucous epidermal nevus. J Dermatol 2010;37:384-6.

35. Hohenleutner U, Landthaler M. Laser therapy of verrucous epidermal naevi. Clin Exp Dermatol 1993;18:124-7.

36. Baba T, Narumi H, Hanada K, Hashimoto I. Successful treatment of dark-colored epidermal nevus with ruby laser. J Dermatol 1995;22:567-70.

37. Park JH, Hwang ES, Kim SN, Kye YC. Er: YAG laser treatment of verrucous epidermal nevi. Dermatol Surg 2004;30:378-81.

38. Boyce S, Alster TS. CO2 laser treatment of epidermal nevi: long-term success. Dermatol Surg 2002;28:611-4.

39. Thual N, Chevallier JM, Vuillamie M, Tack B, Leroy D, Dompmartin A. Laser CO2 continu dans le traitement des hamartomes epidermiques verruquex. Ann Dermatol Venereol 2006;133:131-8.

40. Lopez V, Lopez I, Ricart JM. Successful carbon dioxide laser treatment for verrucous epidermal nevi on the nipple. Dermatol Surg 2013;39(12):1936-7.

41.Sachdeva S, Dogra A. Radiofrequency ablation in dermatology. Indian J Dermatol 2007;52:134-7.

42. Hetigger DF. Soft tissue surgery using radio wave techniques. J Am Pediatr Med Assoc 1997;87(3):131-5.

43. Lolis MS, Goldberg DJ. Radiofrequency in cosmetic dermatology: a review. Dermatol Surg 2012;38(11):1765-76.

44. Savant SS. Radiosurgery. In: Savant SS, Gore D, Atal Shah $\mathrm{R}$, Sarangi K, editors. Textbook and atlas of dermatosurgery and cosmetology. $2^{\text {nd }}$ ed. Mumbai, India: ASCAD; 2005. p. 305-14.

45. Iushkin AS, Berlev OB, Kalashnikov SA, Kolts AV. Features of radio wave tissue dissection in surgical practice. Vestn Khir Im I I Grek 2003;162(1):26-31. (Russian)

\section{Ablacija verukoznog epidermalnog nevusa pomoću radiotalasa - prikaz slučaja}

\section{Sažetak}

Uvod. Epidermalni nevusisu sastavljeniod keratinocita, a kategorisani su na sledeći način: keratinocitni nevusi, sebacealni nevusi, folikularni nevusi, apokrini nevusi, ekrini nevusi, inflamatorni epidermalni nevusi, ostali nevoidni epidermalni poremećaji (linearni lihen planus, nevoidna psorijaza, linearna parakeratoza, Hailey-Hailey-like epidermalni nevus, Darier-like epidermalni nevus, atrofoderma Moulin, Blaschkitis) i sindrom epidermalnog nevusa. $\mathrm{Na}$ osnovu rezultata molekularnih istraživanja, pretpostavlja se da svi epidermalni nevusi predstavljaju abnormalni ćelijski klon u okviru genetskog mozaicizma nastalog iz somatske mutacije.
Epidermolitični i non-epidermolitični verukozni nevusi mogu se međusobno diferencirati skoro isključivo na osnovu patohistološke analize (prisustvo, odnosno odsustvo epidermolitične hiperkeratoze). Ova diferencijacija nema samo akademski, nego i praktičan značaj, s obzirom na to da za razliku od osobe koja ima non-epidermolitični nevus, osoba sa epidermolitičnim nevusom poseduje povišen rizik za nastanak gonadnog i kutanog mozaicizma, što za posledicu može imati rađanje deteta sa autozomno dominantnom buloznom ihtioziformnom eritrodermijom. Iako stepen rizika nije precizno utvrđen, neophodno je pravovemeno informisati i instruisati obolelu osobu. 
Bradavičast, smeđ izgled i odsustvo inflamacije, izdvaja verukozni nevus od ostalih epidermalnih nevusa, a prisustvo na rođenju i perzistiranje, omogućuju diferenciranje verukoznog epidermalnog nevusa od linearnih virusnih bradavica.

$\mathrm{Na}$ samom rođenju, epidermalni verukozni nevus se može manifestovati prisustvom vezikulica, da bi tek u kasnijem periodu poprimio bradavičast izgled. U većini slučajeva, verukozni epidermalni nevus na rođenju poprima macerirani, beličasti izgled, koji se već nakon nekoliko dana menja u ružičaste ili lako hiperpigmentovane linearne somotaste formacije ili plakove. U detinjstvu dobijaju bradavičast izgled. Veličina i distribucija verukoznog epidermalnog nevusa može veoma varirati. Po pravilu verukozni epidermalni nevusi su asimptomatski. U principu imaju u najvećem broju slučajeva benigni tok, tako se njihova terapija sprovodi uglavnom zbog estetskih razloga. Postoji veći broj terapijskih modaliteta za otklanjanje verukoznog epidermalnog nevusa, ali su i lokalna konzervativna i klasična hirurška terapija udružene sa visokom stopom recidiva. U objavljenim radovima koji se odnose na ishod terapije, uglavnom se ne navodi da li se radilo o epidermolitičnom ili o non-epidermolitičnom verukoznom epidermalnom nevusu.

Prikaz slučaja. U radu je prikazan slučaj inače zdrave dvadesetjednogodišnje osobe ženskog pola iz čije se anamneze saznalo da je promenu zbog koje se javila na pregled imala još na rođenju i da se tokom života ona povećavala tako da je u datom trenutku postala i estetski i funkcionalni problem. U porodici nije bilo obolelih srodnika niti je iko od srodnika imao tumore kože. Prilikom prvog pregleda, na desnoj zigomatičnoj regiji lica uočena je solitarna unilateralna verukozna žućkasto prebojena karfiolasta jasno ograničena tumorska lezija, koja se prostirala horizontalno u dužini od oko $3 \mathrm{~cm}$ prateći Blaschko liniju od svog šireg karfiolastog kraja dijametra oko $1,5 \mathrm{~cm}$ smeštenog u desnoj zigomatičnoj regiji do užeg, nalik na rep, debljine $0,5 \mathrm{~cm}$, na desnoj preaurikularnoj regiji, ne prelazeći pritom središnju liniju lica.

Dijagnoza verukoznog epidermalnog nevusa postavljena je na osnovu anamneze, kliničkog izgleda metodom isključivanja. S obzirom da je pacijentkinja odbila uzimanje biopsije, nije bilo moguće izdiferencirati da li se radi o epidermolitičnom ili nonepidermolitičnom verukoznom nevusu, ali je data informacija o mogućem riziku za dobijanje potomstva sa buloznom ihtioziformnom eritrodermijom i mogućnosti, tj. neophodnosti sprovođenja antenatalne dijagnostike.

Lezija je uspešno odstranjena pomoću ablacije radio talasima pomoću radiotalasnog noža (radiotalasni nož , Proxima VF, Proxima V.F, Proxima D.O.O, 18250 Niš, Srbija), pod lokalnom anestezijom (EMLA' krem). U prvoj terapijskoj seansi korišćen je incizioni produžetak (elektroda izgleda tanke igle) i to u položaju sečenja sa koagulacijom, intenziteta 6/7 (raspon od 0 do 9). U drugoj terapijskoj seansi koja je sprovedena sedam dana kasnije, ivice promene su dodatno „dorađene“ metodom topljenja pomoću sferičnog produžetka (elektroda sferičnog oblika) radiotalasnog noža, istim intenzitetom $\mathrm{i} u$ istom položaju: sečena sa koagulacijom. U daljoj terapiji korišćena je antibiotska mast sedam dana a potom je nastavljena lokalna aplikacija gela protiv ožiljaka. $\mathrm{Na}$ kontrolnom pregledu sprovedenom četiri nedelje kasnije, verukozna promena bila je u celini odstranjena, bez ožiljaka a na tretiranom mestu zaostao je samo blag eritem. S obzirom da verukozni epidermoidni nevus ima sklonost ka recidiviranju, delimičnom i kompletnom, pacijentkinji je savetovano da dolazi redovno na kontrole i da se maksimalno štiti od sunčevog zračenja tokom letnjih meseci.

Diskusija. S obzirom da se u osnovi i epidermolitičnog i non-epidermolitičnog verukoznog nevusa nalazi mozaicizam, oni se ne mogu preneti sa roditelja na decu niti se pojaviti u istoj porodici. Verukozni epidermoidni nevus predstavlja neinflamatorni kongenitalni kutani hamartom koji je sastavljen od keratinocita koji čini abnormalni klon ćelija u okviru genetskog mozaicizma nastalog iz različitih somatskih mutacija. Neke od ovih mutacija su dobro ispitane ali su mnoge još uvek neidentifikovane. Dokazano je da epidermolitični verukozni epidermalni nevus predstavlja klon ćelija koje poseduju mutacije jednog od gena za buloznu ihtioziformnu eritrodermiju. KRT10 i KRT1. Kao takav, verukozni epidermoidni nevus se ne može preneti sa roditelja na dete a za razliku od non-epidermolitičnog verukoznog nevusa koji je posledica mozaicizma za različite, još uvek nedovoljno identifikovane mutacije. Roditelj koji ima epidermolitični verukozni nevus može imati povišeni rizik od nastanka gonadnog i kutanog mozaicizma, 
te tako može imati potomstvo sa generalizovanom buloznom ihtioziformnom eritrodermijom. Iako navedeni rizik nije još uvek egzaktno kvanitifikovan, neophodno je pacijentu dati savet i dalje instrukcije. Za razliku od epidermolitičnog verukoznog nevusa gde mutacije zahvataju gene za keratin koji se nalaze samo u epitelu, non-epidermolitični verukozni epidermalni nevus, predstavlja posledicu mozaicizma nastalog iz različitih još uvek nedovoljno identifikovanih mutacija i može (u oko $10 \%$ slučajeva) biti udružen sa ekstrakutanim poremećajima, najčešće centralnog nervnog sistema, oka i skeleta (npr. epidermalni nevus sindrom). $U$ verukoznom epidermalnom nevusu mogu se, iako retko, razviti: Bovenova bolest, verukozni i adneksalni karcinomi, bazocelularni karcinom, spinocelularni karcinom; još uvek nije razjašnjeno da li ove promene predstavljaju rezultat specifičnih razlika vezanih za lokalizaciju promena i starost osobe u samom nevusu ili se radi o različitim nevusima. Kod našeg pacijenta ovakve promene nisu nađene.

Terapijski modaliteti su brojni a mogu se koristiti u zavisnosti od lokalizacije i veličine lezije sa različitim uspehom. Lokalnu konzervativnu ali i klasičnu hiruršku terapiju prate recidivi, ukoliko se istovremeno pored epidermisa ne odstrani i susedni dermis. U terapiji se mogu koristiti topikalni ili intraleziono kortikosteroidi, kalcipotriol, 5-fluorouracil, podofilin, retinoid, hemijski piling, krioterapija, dermoabrazija, elektrokoagulacija, fotodinamička terapija, različiti tipovi lasera (argon ruby, erbium: yttrium aluminium garnet - Er: YAG, carbon dioxide).

Poslednjih godina radiofrekventna ablacija (sinonimi
- radiohirurgija, visoko- frekventna elektrohirurgija) postala je značajna kao efikasan terapijski modalitet u svakodnevnoj dermatohiruškoj praksi. Zato smo ablaciju verukozno epidermalnog nevusa kod naše pacijentkinje izveli pomoću radiotalasnog noža Proxima VF. Ovaj nož predstavlja moderan visokofrekventni radiohirurški instrument sposoban $\mathrm{da}$ pretvara električnu struju u radiotalasnu frekvenciju na principu povećanja frekvencije i voltaže i istovremenog smanjenja jačine - amperaže naizmenične struje. Daljom modifikacijom i postizanjem različitih talasnih formi, postižu se tri glavna efekta na tretiranom tkivu: elektrosekcija (isecanje), elektrokoaugulacija (destrukcija dubokog tkiva) i elektrodesikacija/ elektrofulguracija (destrukcija površnog tkiva). Odabir talasne forme kao i oblika vrha elektrode (fina igla, žičana omča, elipsa ili trougao, dijamant), zavisi od primarnog cilja, npr. isecanje ili koagulacija. Radiofrekventna ablacija je postala popularna zbog nekoliko prednosti u odnosu na ostale hirurške procedure, naročito u odnosu na elektrokoagulaciju, klasičnu i lasersku hirurgiju: predstavlja jednostavnu metodu, lako izvodljivu, brzu, manje bolnu - uglavnom bezbednu tehniku, sa manjim zagrevanjem i destrukcijom okolnog tkiva, sa značajno manje komplikacija i neželjenih efekata. Bez obzira na sve i ovde je indikovano praćenje s obzirom na mogućnost čestih recidiva.

Zaključak. U ovom radu prikazujemo slučaj lokalizovane forme kongenitalnog verukoznog epidermalnog nevusa kod inače zdrave mlade osobe ženskog pola koji je uspešno tretiran radiofrekventnom ablacijom.

Ključne reči: Sebaceozni Jadassohnov nevus; Prevalenca; Dijagnoza; Ablativne tehnike; Prikazi slučajeva; Ablacija kateterom 